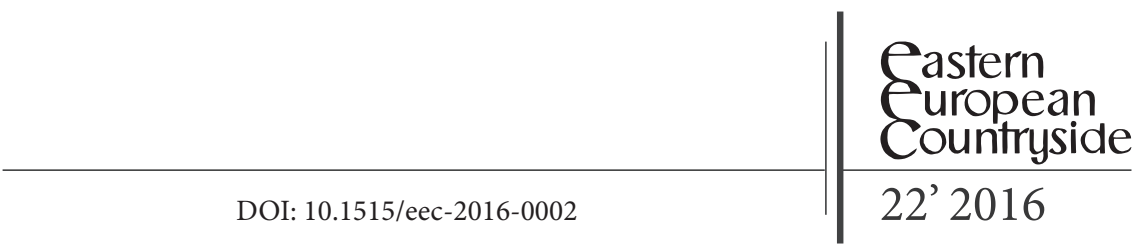

Maria Halamska

Institute of Rural and Agricultural Development, Polish Academy of Sciences, Warsaw, Poland

\title{
The Evolution of Family Farms in Poland: Present Time and the Weight of the Past
}

\begin{abstract}
The author provides an analysis of family farming in Poland during the period 1990-2012, with special attention towards the close links of ownership and the operation of the farm by family members. The weight of various factors is given close attention, including the historical context of the farm, current conditions, and future intentions for the farm.

The historical context acknowledges and stresses the importance of the late abolition of serfdom made by the partitioning powers, various agricultural reforms during the period 1919-1944, and the period 1948-1989 (when family farming was incorporated into a deficient centrally planned economy). This latter period saw family farms developing specific mechanisms of functioning, which can be seen two decades later. Analysis of the period 1990-2012 is based on data of the Central Statistical Office, the present study, and other published materials. The data series includes individual farms of more than 1 ha, based on family labour.

Separated are two sub-periods: the post-communist transformation period from the early 1990s, and the period 2002-2012. The latter almost coincides with the accession to the EU. In the first period, the article outlines the process of creating duality in Polish agriculture. This describes a group of family farms where the household strongly reacted to the market and became larger and
\end{abstract}


modernised (professional $-1 / 3$ of the total) and small, extensive and producing mainly for own consumption (semi-subsistence - 2/3). In the second period, the functioning and transformation of households taking place under the CAP are examined. Modernisation is primarily seen on the professional farm. Specific mechanisms can be seen that provide fairly stable functioning of semisubsistence farms, independent of the market, with non-farm incomes and agricultural social security. These farms resisted collectivisation and stopped and hindered modernisation during the communist period, and this post-communist transformation now requires a doubly controlled modernisation process.

Keywords: Polish family farming, a specific evolution, agriculture dual, professional farm, quasi-peasant farms

\section{Premises}

Family farming in Poland has developed along a special path, which applies not only to the distant past but also to the 20th century, when its transformation occurred in accordance with two fundamentally different models: the Danish and the Soviet. ${ }^{1}$ I assume here that the specific class of socio-economic phenomena called 'family farms' is contemporarily quite varied, and the actual conditions and functioning of such farms depend on three groups of factors: the weight of the past, plans for the future, and present conditions in the broad sense. The prototype is the peasant farm, but a family farm is a broader category. As it is emphasised by everyone who studies them, family farming and family farms are very difficult to define. There is no universal definition of a family farm, as family farming and family farms are 'long-duration' phenomena, the effect of various evolutions, and their present large differentiation also results from the current diversification of economies and societies, the level of development of agriculture, and the various types of socio-political orders. This simultaneously testifies to

1 Michel Sivignon distinguishes three models in the development of European agriculture: the English (limited, in principle, to the British Isles), the Danish (which spread in a number of variants throughout Continental Europe), and the Soviet (constructed by the Soviet Union and imported to Central Europe) (cf. Sivignon 19921993). 
the enormous flexibility of family farms - to their great ability to accommodate themselves to various economic and socio-political systems.

In accordance with the CIRAD ${ }^{2}$ report, I consider that "family farming is one of the forms of organizing agricultural production, encompassing farms characterized by organic links between the family and the production unit, and by work being performed by the family rather than by permanent hired labour. These links are manifested by the inclusion of production capital in the family patrimony and by the combined logic of domestic and exploitative, market and non-market operations in the process of allocating the family's work and its remuneration, as well as in the manner of dividing products between final and intermediary consumption, investment, and accumulation" (CIRAD 2013, p. 13); a family farm is an agricultural production unit where the ownership, management and work are closely associated with a family (Lamarche 1991). ${ }^{3}$ In referring to this general definition of a family farm and putting it into the language of mass statistics, I consider that family farms are private individual farms, ${ }^{4}$ which - and here an important defining quality is added - primarily make use of family labour.

\section{Long duration}

The French historian Marc Bloch claimed that the history of a country or region could be recreated on the basis of its agrarian structure. In the case of Polish

2 Report prepared by CIRAD (Centre de Coopération Internationale en Recherché Agronomique pour le Développement) on the occasion of the UN International Year of Family Agriculture. CIRAD 2013 Les agricultures familiales du monde, Montpellier. It appeared in book form in 2014, entitled L'agriculture familiale et le monde a venir, Editions Quae.

3 In general, when more precise definitions are attempted, they lose their universality (cf. the definition of Andrew Errington and Ruth Gasson 1993). In addition, the phenomenon of the 'family farm', its definition, its description, and especially the functions ascribed to it are frequently encumbered with value judgments (cf. wellknown theorists of family [peasant] farming, such as Martha Strong (2008) and Jan Douve van der Ploeg (2008)). The existing statistical or formal-legal definitions very often have hidden political assumptions as well.

4 I make use here of the idea of an 'individual farm', which the Main Statistical Office has defined since 1988 as a farm with an area of more than 1 hectare of agricultural land. 
agriculture, the influence of political and social history is very legible, at least from the $16^{\text {th }}$ century, when the $1^{\text {st }}$ Republic's principles of manorial serfdom were formed. It comprised manorial estates belonging to the nobility and based on serf labour. The foundation of the economy then was the cultivation of grain, which was exported to the West. We should remember that this was at the beginning of the formation of the global economy, and this grain economy - as Witold Kula has documented (1983) - determined Poland's 'ejection' to the economic periphery of Europe and, later, of the world.

The second period that has negatively impacted the condition of family farming in Poland is the period of the Partitions, which lasted 120 years. I consider that several elements should be emphasised here. Firstly, the emancipation of the serfs occurred late, or very late, in Polish lands: a) by the partitioning states, b) during various periods, and c) according to varying principles. ${ }^{5}$ It should be remembered at the same time that the 19th century in Europe was a period when nation states were emerging. Henri Mendras (1995) points to the importance of farming people in this process: the idea of the nation, which developed in Western Europe at the beginning of the $18^{\text {th }}$ century, is connected with stable, free farming people: people who have their own language and land and, thus, can form a nation, divisible from others by borders, which, as they define a state of possession, the people will want to defend. At this time, Poland was divided between three multinational empires and it was they who conferred freedom on the serfs. A clear signal of the existence of a national consciousness among Polish peasants appeared only with the war of 1920. Furthermore, the Polish lands, belonging to three great powers, were located on those powers' peripheries. They were parts of significantly differing state organisms, with differing economic systems, legal systems, and scales of political repressiveness. This determined the varying rhythm of economic development, the progress of modernisation in agriculture, and the implementation of the achievements of the first agricultural revolution.

5 In the Prussian Partition, it occurred between 1808 (the territories incorporated into Prussia) and 1823 (the Grand Duchy of Poznań); in the Austrian Partition, it began in 1848 and lasted 10 years; and in the Russian Partition, it happened in the years 1861 (the lands attached to Russia) and 1864 (the Congress Kingdom). The principles of enfranchisement, including within one partition, were slightly different depending on the status of the land. 
The years 1919-1948 - in spite of the crisis of the thirties and the war-were, in sum, years favouring family farming: it was, after all, a time of agricultural reforms. Their course and outcomes are, however, very telling. Agricultural reform, which was announced in a parliamentary resolution of 1919, only passed into law on 15 July 1920, at the moment of the Bolshevik offensive against Poland. The reform was never introduced in practice, however, due to the contradictions between its principles and the Constitution passed in 1921. Another act on agriculture was passed in 1926 and amended in 1933. By the outbreak of the Second World War, nearly 2.6 million hectares had been parcelled out to peasants with little or no land, but almost one third of farmland remained in the form of large estates. In Poland during this period, in spite of the essentially dual form of agriculture, the Danish model began to spread, particularly in the Wielkopolska region: peasant commodity farms were together creating a cooperative-associative farming infrastructure. The idea of this model of agriculture was promoted, after Danish patterns, by adult education programmes.

All of the organisations related to agriculture, with numerous peasant political parties in the lead, helped to create the 'infrastructure' of agrarianism: an ideology glorifying people who work the land and proposing a social order of which they would be the social base. A description of such a social order can be encountered in the agrarian writings of Władysław Grabski, ${ }^{6}$ for example, and an excellent reconstruction of the ideal type of peasant consciousness and personality formed by agrarianism and its institutions can be seen in Józef Chałasiński’s Młodym pokoleniu chłopów [The Young Generation of Peasants]. The period of agricultural reform ended with the radical agricultural reform of 6 September 1944, when 9,707 landed estates, comprising a total area of 3.5 million hectares, were parcelled out or 'socialised'. In the years 19441948 , only 1.2 million hectares of land were distributed to the peasants, while the rest formed the National Land Fund (PFZ). In the Northern and Western territories, a further 5 million hectares were redistributed. This radical agricultural reform eliminated large commodity farms and the gentry as a layer, but had a negligible impact on peasant farming: the average size of a peasant farm grew by .4 of a hectare - from 5 hectares in 1938 to 5.4 hectares in 1950 .

6 Cf. on this subject (Sieliwończyk 1983). 


\section{Arrested collectivisation, hindered modernisation}

The next 40 years, the period from 1948 to 1989, have been described repeatedly, including with regard to their specific nature in Central Europe: the policy of the then-authorities towards the farmers became the basis of a phenomenon called the 'Polish road to socialism'. Its particular traits have been decoded in such works as Marxisme et lagriculture by Jerzy Tepicht (1973), On the Repressive Tolerance by Krzysztof Gorlach (1989), ... potega jest $i$ basta [..There's a Power and That's That] by Bohdan Cywiński (1981), and Les paysans contre l'Etat by Marie-Claude Maurel (1989). It was a diverse era and began with forced collectivisation, which lasted until 1956. The period was significant, less for its collectivisation of agriculture (that is, the establishment of collective farms, most of which collapsed after the cessation of repression) than for its destruction of the institutional framework of the Danish model, which had been created in the interwar period. Large commodity farms owned by families became harassed kulak farms; agricultural organisations (associations) ceased to exist; the socalled battle for trade destroyed private business; and the collectivism that had developed during the interwar period was practically nationalised. The United People's Party [ZSL], which had emerged as a result of the unification of the peasant movement, lost its independence and autonomy. Furthermore, as a result of a reform of the territorial division of the nation and the establishment of gromady (administrative units) in the place of the existing gminy (districts), local social networks were broken and rural authorities destroyed. This was a period of repression of the peasants, when the state, through physical force and financial burdens, attempted to destroy family farming. The end of forced collectivisation after 1956 did not change the prevailing economic exploitation of peasant farming, which financed the basic costs of industrialising the country.

Peasant farming, obviously, changed as well. After 1956 it began slowly to modernise; the 'conception consisted in preserving the output potential of individual family production while simultaneously subordinating it to the centralized method of directing the whole economy. From the beginning, this conception was mired in contradictions and thus led, it would appear, to what [...] we call the period of "hindered modernization"" (Kochanowicz 1988: 85). This defective modernisation was, above all, 
a technical modernisation, oriented towards increasing yields and ensuring at least the minimum required access to machines and industrial means of production. It did not allow for either the increase of farm areas or their specialisation. This was 'growth without development', as Waldemar Kuczyński (1981) described it. Nevertheless, large numbers of the labour force left their overpopulated family farms to work elsewhere, although they retained their land; these became peasant labourers. Through income from work outside of agriculture, farming families were able to acquire additional funds for investment and consumption. After 1970, the state policy towards family farming underwent a change. The system of obligatory supply was lifted; thus, there was an opportunity for farms to specialise. The pool of industrial production means was increased for family farms; credit lines were set up; and a programme of so-called specialised farms was created. These were the forerunners of family commodity farming; in Poland they were usually called 'farmerski' farms. This more advantageous policy for family farming broke down in the middle of the seventies, though, and socialised agriculture (state farms and agricultural cooperatives) was still favoured.

Thus, in a period when a revolution was occurring in the modernisation of agriculture in Western Europe, the People's Republic of Poland was establishing rules for the presence of family farming in a centrally planned economy and a communist society. These rules were not permanent or precise and could change at any moment, as is typical in a 'prerogative state. The space in which family farming operated was characterised by uncertainty, which could be increased or reduced depending on the will of the political centre. Ownership of the land, and the permanency of family (individual) farms, was insecure. In accordance with the first basic principle of real socialism, peasant farming was subjected to all-encompassing control. The areas of farms, access to production means, the purchase of agricultural products, credit, and even - through the system of obligatory supply - a farm's structure of production were all subject to state control. The functioning of those farms, and the reason for their presence in a communist economy, is thus intriguing. Jerzy Wilkin's analysis (1988) is convincing here. He rejects the fairly common hypothesis of the time about the subsumption of peasant farms, ${ }^{7}$ and, using the theory of the adaptation of systems, claims that what occurred was the merging

What is meant is subordination to the communist economy while preserving traits of considerable autonomy. 
of peasant farms with the communist economy. ${ }^{8}$ In agreeing with this idea, I would even claim that towards the end of the eighties, peasant farming was in symbiosis with the communist economy of scarcity (Halamska 1999). Not only the situation of all-inclusive control, but also the situation of scarcity, of a permanent lack, had an important impact on the mechanisms by which family farms functioned, the behaviour of farmers, and family farming's place in society. The mechanism of competition was fundamentally warped: farmers competed for the means of agricultural production from a political administrator, rather than the producers of such means competing for the farmers' business; on the other hand, it was the consumers who competed for products, not the farmers who competed for consumers (through quality or mode of supply). ${ }^{9}$

Such a situation was shaped by a specific rationale in the functioning of most farms. As a result of the chronically unmet demand for basically every kind of food in the economy of scarcity, nearly all farms were commodity farms (to varying degrees). In terms of sales, this was a comfortable situation for agricultural producers, eliminating the principle of competition from their operating mechanisms. Scarcity in the market (both of production means and of consumer items) and the additional influx of funds to family farms influenced the manner of asset accumulation on farms. It was strongly conditioned by social considerations and only partially determined by reasons of production or economics. The possession of means of production - machines, above all - which were difficult to acquire, became (in a certain sense) an end in itself; the question of the reasonableness of their use in the production process was a secondary consideration, as was indicated by the limited effectiveness of the use of fixed assets. This meant that investment

8 It is thus assumed that a communist economy is an artificial system and a peasant economy is a natural one. 'As a result of the adaptation of systems a transition is made from a state of systemic heterogeneity to a state of systemic homogeneity. This is a condition for the internal stability and development of the system. This mechanism, which acts as a transmitter of incentives and energy, is a phenomenon described in general systems theory as feedback. The system or subsystem that predominates will depend on the impact and adaptive efficiency of the structures participating in this process. What is certain is that none of them will remain unchanged' (Wilkin 1988: 22).

9 I am leaving aside here the social consequences: the emergence of spheres of paternalist-clientelist interdependence, functioning according to the principles of amoral familism. 
was only partially amortised economically, in the sphere of production. In part, this amortisation was of a socio-psychological nature: the investment limited the sense of uncertainty, produced a greater feeling of autonomy, and served to recreate or create social status. Thus, while family farms in the West were turning to economics-based operation, in Poland the opposite process - a specific socialisation - was occurring: the operation and reproduction of family farms underwent a 'familisation'. In many cases, farming became a way of life and not an economic process. In a word, family farms adapted to the communist economy, which also meant that their operating mechanisms became specific and - as would shortly emerge - little suited to an open market economy.

\section{The post-communist transformation: 'oppressive freedom'10?}

In 1988, there were around 2,200,000 individual farms in Poland. ${ }^{11}$ For the most part, these were small or very small farms: over half (53.5\%) did not exceed 5 hectares, $40.5 \%$ had 5-15 hectares, and only $6 \%$ had more than 15 hectares. At the same time, as an analysis of these farms' means of operation shows, only $1 / 5$ could be considered of the self-sufficient, peasant type; $4 / 5$ had fairly close ties to the then-market, and the majority strove for the effectiveness typical of farm businesses (Halamska et al. 2003; Maurel et al. 200?). Already in 1989, with the freeing of farm prices, the elemental process began of family farming's adaptation to the market economy, in which all of the deformed mechanisms of such farms' functioning had to be corrected. This was a quite brutal process, as it occurred during the period of the liberal transformation of the entire economy. It was a situation in which:

- the state (though only briefly) withdrew the support and protection of its own agriculture: the PSE (Producer Support Estimate) fell from $28 \%$ during $1986-1988$ to $9 \%$ in 1989 , to $-13 \%$ in 1990 , and to $-3 \%$ in 1991. At the same time, the economy was opened and the influx of agricultural products and food was uncontrolled;

10 I am referring here to the article by Krzystof Gorlach and Zygmunt Seręga entitled 'From Repressive Tolerance to Oppressive Freedom: Polish Family Farms in Transition' (1993).

11 Of an area larger than 1 hectare of agricultural land. 
- there was strong (and disloyal - in 1990 the PSE for EU agriculture amounted to nearly 40\%, and in Poland 13\%) competition from foreign food; the import of agricultural products grew (by 130\% in 1991 alone); exports fell; and from 1992 to the end of the 1990s, the balance of trade for agricultural items/food remained negative;

- the institutions serving agriculture collapsed; in the countryside, the widespread farmers' cooperatives (SKR), providing mechanisation services, and the local 'Farmers' Self-Help' District Cooperatives providing the countryside with means of production and consumption, and purchasing agricultural produce - fell apart on a massive scale; gardening cooperatives collapsed, etc.

- as a result of the economic transformation, some of the peasant labourers were forced back to their farms and, at the same time, the outflow of labour from agriculture was not absorbed. The effect was a growth of employment in family farming, a growth in rural unemployment, and a drop - particularly towards the end of the decade - in real agricultural incomes. ${ }^{12}$

Farmers, not being the object of repression, experienced 'oppressive freedom, to which they reacted politically through a series of organised protests. ${ }^{13}$ The state's undertakings, which, in fact, lacked consistency and did not rely on past models, were underappreciated by both farmers and analysts of the period (economists and sociologists); they created a new environment for farming - the infrastructure for modern agriculture. Slowly, there arose:

- new institutions, which were to become the instruments of state intervention: in 1990, the Agricultural Market Agency; in 1992, the Fund for Debt Reduction and Agricultural Restructuring (after 1994, the Agency for Restructuring and Modernization of Agriculture); in 1992, the Agricultural Property Agency of the Treasury (from 2003, the Agricultural Property Agency).

There also emerged:

- a system of social security and social aid for farmers. In 1990, legislation was passed for the social security of farmers. This special system, which was very beneficial for farmers and household members

12 This period is not homogeneous; its particular characteristics, with statistical documentation and division into phases, can be found in Halamska et al. (2003).

13 Cf. on this subject (Foryś 2008). 
working on the farm, came to be operated by the Agricultural Social Insurance Fund (KRUS), and was largely financed by the state budget and absorbed the majority of the funds earmarked for agriculture.

Also in 1992:

- the universal tax system that was introduced did not encompass income from agricultural production (with the exception of certain special areas). Farmers paid only the so-called 'agricultural tax'.

As a result of the influence of these factors, a process of change began in family farming in Poland. In an elemental manner, though with the participation and permission of the state, a new dual agriculture emerged. Its first obvious sign was a change in the structure of farm types: 'a disappearing middle' (the rapid decline of farms of 5-15 hectares), the stabilisation of the group of small farms, and the strong growth of larger farms (see table 1). The rapid growth of the group of the largest farms and the visible concentration of land in this period resulted from the privatisation of the state agricultural sector. The principles and geography of privatisation favoured the emergence of new farms (not necessarily family ones) and, to a much lesser degree, the enlargement of existing farms. The second sign of farming's dichotomisation concerned changes in the manners and aims of farming, as indicated, above all, by the relation of family farms to the market.

The post-communist transformation commenced the 'end of the peasants' in Poland: a process typical of a developed market economy and modernised agriculture. In Poland, it occurred in a specific manner: besides the 'de-familying' of part of the farms (primarily larger farms of the family-business type), as documented by Krzysztof Gorlach $(2001,2009)$ and later by Alina Sikorska (2014), the process of apparent 're-peasantisation' is significantly more visible. Many facts point to this: the growing number of persons working in agriculture, the relinquishment or limitation of contacts with the market, etc. Panel studies conducted in 1988 and 2001 document that: ${ }^{14}$

- there was a very clear decline in the number of farms strongly connected with the market (business-type farms), which had become either self-sufficient farms or a transitional type, waiting and gaining

14 The authors of these studies were Marie-Claude Maurel, Hugues Lamarche, and Maria Halamska. A detailed analysis of the dynamic is to be found in their joint book entitled Rolnictwo rodzinne w transformacji postkomunistycznej: Anatomia zmiany [Family Farming in the Post-Communist Transformation: An Anatomy of Change] (Halamska et al. 2003). 
strength; on the other hand, there was a negligible crossover of peasant or transitional-type farms to the business type, and there was a large growth in peasant-type, self-sufficient farms;

- some of the business-type farms grew stronger, significantly increasing their land areas and fortifying their ties with the market; many were formerly specialised farms;

- there was growth in the number of transitional-type farms and strong growth in self-sufficient, peasant-type farms; many of these decreased in size, and there was a decline in the intensity of farming and the commercialisation of products; ${ }^{15}$

- there was a diversification (divergence) in farmers' strategies with regard to the land, depending on the type of farming; ${ }^{16}$

- on part of the farms the labour resources increased; these were primarily smaller farms. ${ }^{17}$

In reality, the post-communist period of transformation has been one of irreversibly diverging trajectories of economic evolution - the process of dualisation of family farming, based (above all) on the nature of ties to the market: around $1 / 3$ of farms are connected with the market, modernising or having the opportunity to modernise; around $2 / 3$ are small farms, becoming marginalised and, in the majority, aiming for the peasant, selfsufficient model. 'The heads of these non-market-oriented farms consider that they live like peasants, but in reality the bases of their income comes from outside agriculture. A family farm ensures the social status of its head and of the members of his family who find shelter there. But are those farm-holders,

15 Hugues Lamarche, author of this part of the analysis, comments on the situation as follows: 'This analysis of evolution of farms' manner of functioning (...) shows the decline of comparatively prosperous family farming that has occurred in the course of the last not quite 13 years (...) More than two-thirds of farms have been marginalized. It would be entirely logical to assume that this evolution will be accompanied by a deep change in relation to inheriting the farm' (Halamska et al. 2003: 65).

16 Marie-Claude Maurel, author of this part of the analysis, claims that 'the peasant type is dominated by the logic of disposing of or preserving family land assets, while in farms functioning according to business models, there was a strategy of accumulation or waiting for an opportunity for realization. On the other hand, in farms of the transitional type, which display the mobility of this group, we find a large diversity in land models' (ibid.: 98).

17 'Hidden unemployment has 'settled in', above all in farms of the peasant type, where nearly all (96\%) are characterized by very high rates of employment. Transitional-type farms are also very labour intensive ...' (ibid.: 77). 
who have reduced the dimensions of their production, simplified their system of cultivation, and relinquished animal production, still farmers? Is this still the peasant manner of farming, which still characterized these farms ten years ago, if the family 'farm' has ceased to produce profit from work on the farm, and even ceased to produce for its own needs? Willingness to be maintained from social benefits and life on a phantom farm is very far from the traditional peasant ethic' (ibid.: 100). It is the specific rules of functioning of such farms that suggest they should be called quasi-peasant farms, and their users quasipeasants. The appearance and continuation of these collectives have provided me with the basis for positing 'a different end of the peasants' in Poland. ${ }^{18}$

\section{Controlled (dual) modernisation and its effects}

A new, dynamic, and predictable stage of the transformation occurred at the moment of Poland's entry to the European Union, as agriculture was provided with the model towards which it was supposed to strive: the European model of agriculture. This was, as it would shortly appear, a moveable goal: developed during the productivist period and corresponding to the needs of an industrial society, in a post-industrial society it had necessarily to change. The direction in which the model changed seemed to indicate a paradigm of balanced development, from which two concepts emerged: multi-functional agriculture and balanced agriculture. This does not change, however, the very important role of the state in this model of agriculture. But instead of the state and its active role in the modernisation of agriculture (the effect of globalisation), there was now the European Union and its common agricultural policy, divided into so-called pillars. The Polish state became a very important decision-maker, but a secondary one, implementing subsidiary aims, which influence the manner of achieving the main goal. The modernisation of family farming is thus a (dually) controlled process. Control of the process of change is multi-level and occurs through accepting the so-called acquiscommunautaires, the negotiated quotas of certain products, funds, and national principles of introducing the policy. From the moment of accession (in 2004), enormous funds have flowed into agriculture in a regular and foreseeable manner. On one

18 I analyse this question at length in the text 'A Different End of the Peasants?' (2004). 
hand, they have significantly improved the incomes of farmers (in the years 2004-2013, within the direct payments framework, SAPS, farmers received 105 billion PLN) ${ }^{19}$; on the other hand, they have enabled the structuralised and controlled modernisation of farms: funds from the SAPARD programme, the Sectoral Operational Programme Agriculture in the years 2004-2006, and the Rural Development Programme in the years 2004-2006 amounted to 6.3 billion euros; and from the RDP in 2007-2013, 17.4 billion euros, of which the majority (around 70\%) went to farms. Here, a major role falls to the state, because it chooses the task and defines the criteria for receiving funds, which simultaneously means that the process acquires a political nature in the narrow sense: the rationale for socio-economic changes is somehow automatically subordinated to the priorities of the alignment of political forces at a given moment.

How have the changes in family farming proceeded during this period? Economists primarily follow the changes in the pool of factors of production and the mutual relations between them. The primary resource is land: the area of farmland, around 14 million hectares, has not changed in the entire decade. There has been a decided fall in employment in agriculture, although the number of persons working in agriculture is still very large; ${ }^{20}$ thus, the average productiveness of work is low. The structure of capital points to investments aimed at increasing the intensity of production. Analysis of the growth of farms during the period 2002-2012 seems to confirm the hypothesis, made after 10 years of the post-communist transformation, about the progressing dualisation of family farming in Poland: the changes are happening at a slightly different rhythm, but their direction remains the same.

Table 1. Changes of individual private farms above 1 ha of arable land

19 This constitutes around 26 billion euros. These are not precise data, as the national statistics give direct payments in PLN. The sums given in euros are from my own calculations (the sum of payments in a given year divided by the average exchange rate for the euro in regards to the zloty (PLN) in that year).

20 There is no agreement among specialists over either the number of those employed in agriculture or the trends in employment. Frenkel, on the basis of Labour Force Survey (BAEL) data, points to the above-mentioned fall in employment. BaerNawrocka and Poczta, basing themselves on employment figures at the end of each year, speak of a growth in employment: from 2,109,000 in 2003 to 2,378,000 in 2012, constituting $113 \%$ of persons working in 2003. 


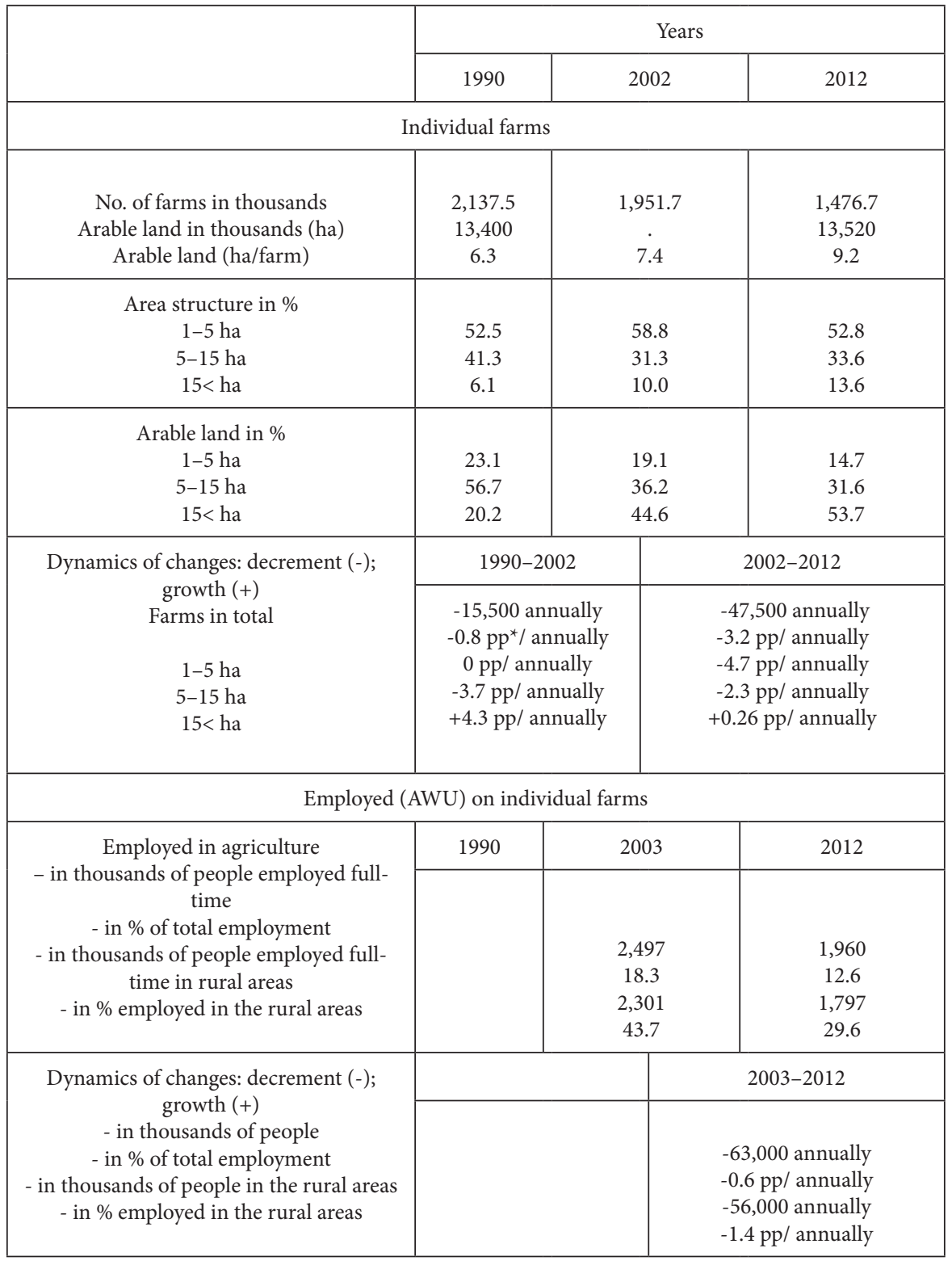

\section{${ }^{\star}$ Percentage points}

Source: own study based on Bauer-Nawrocka and Poczta (2014) and Frenkel (2013). 
Firstly, the very number of farms has undergone a fairly rapid reduction: the tempo of change during the period 2002-2012 is significantly more rapid than during the period 1990-2002. For the earlier period, there was an annual loss of 15,000 farms; and for the period 2002-2012, a loss of around 47,000. The number of larger farms has progressively increased, and there has also been a concentration of land. This tendency is excellently well illustrated in the studies of the Institute of Agricultural and Food Economics. 'In studies of rural areas, the number offarms decreased by 15.2\% between 2000 and 2011. This process is relatively most visible in the group of farms with an area of 10 to 15 hectares, in which more than one in three farms disappeared, and in the group of 5 to 10 hectares, in which there was a loss of every fifth farm. In this connection, it is noteworthy that decidedly more changes in the land structure of farms were noted in the period 2005-2011 than in the five years between 2000 and 2005, confirming the idea that the effect of integration with the EU and of support within the framework of the common agricultural policy had a stimulating effect on activating structural changes in agriculture' [Sikorska 2013, p. 23]. The most rapidly growing are farms above 15 hectares, as their share in the farming structure, the average acreage, and the area in use is growing. Sikorska points to two causes of these changes: the increasing competition in agriculture, which creates pressure for a larger scale of production, and the location of so-called agri-business areas relative to urbanised areas and absorptive labour markets. ${ }^{21}$

The drop in the number of workers during the period 2003-2013 was fairly slow and amounted to only around $0.6 \%$ yearly; among those employed in rural areas it amounted, however, to a loss of $1.4 \%$ annually. The changes have occurred differently among various types of farms, which indicates not only a different dynamic of change, but also primarily a different rationale in the functioning of these groups of farms. This is illustrated by the rate of change in farm size and in employment in farms of various sizes. It is the larger farms that stand out: they are significantly increasing their average area. They are also increasing employment, although the growth rate in area of farmland appears to be stronger than the growth in employment (table 2). These farms are also increasing their production capital, as is shown by the use

21 On the subject of types of rural economy, cf. Marini and Money (2006) and Halamska (2013). 
of Rural Development Programme funds intended for the modernisation of farms.

Table 2. Dynamics of changes in farms of various types

\begin{tabular}{|c|c|c|c|c|c|}
\hline \multicolumn{2}{|c|}{$\begin{array}{l}\text { The increase of average farm } \\
\text { area during the period of } \\
\qquad \begin{array}{l}2002-2012 . \\
2002=100\end{array}\end{array}$} & \multicolumn{4}{|c|}{$\begin{array}{l}\text { The dynamics of those working on farms } \\
\text { during the period of } 2005-2010.2005=100\end{array}$} \\
\hline Area group & Dynamics & Area group & $\begin{array}{l}\text { Working } \\
\text { in total }\end{array}$ & Only on farm & $\begin{array}{l}\text { Also outside } \\
\text { farm }\end{array}$ \\
\hline In total $>1$ ha & & In total $>1$ ha & 92 & 89 & 100 \\
\hline $1-5$ ha & 108 & $1-5$ ha & 82 & 86 & 77 \\
\hline $5-15$ ha & 100 & $5-20$ ha & 95 & 89 & 113 \\
\hline $15-50$ ha & 156 & $20-50$ ha & 102 & 98 & 130 \\
\hline$>50$ ha & 183 & $>50$ ha & 127 & 121 & 167 \\
\hline
\end{tabular}

Source: own study based on Bauer-Nawrocka and Poczta (2014) and Frenkel (2013).

Secondly, the aims of various kinds of farms, as indicated by the degree to which their production is commercial, also point to the existence of different trajectories of change. If we take production directed at the market as an indicator of the kind of farming, then somewhat more than half of family farms have this clear market orientation. A market orientation is stronger in farms that are larger in area: the decided majority of these (70-80\%) intend to sell at least three quarters of their production. At the same time, nearly every third farm is oriented primarily towards self-sufficiency, that is, market requirements have little or no impact on its functioning. Nearly half of smaller farms, in the category of 1-5 hectares, are of this type. These farms also differ in the commercial aspect of their production. In family farming, there are currently two forms of sales: direct sales and sales to the processing industry. The sale of production from small farms is primarily direct: local sales and in markets. Large commercial farms sell their products to processing factories, which increasingly often collect agricultural products directly on the farms. Therefore, the 'domination of these two forms of disposing of the products of individual farming reflects above all their dichotomy. On the one side, there are low production units producing mainly for subsistence, and on the other there are professional farms seeking to achieve the most stable position possible on the market for agricultural products' (Sikorska 2013: 39). Such a position is ensured, among other things, by contracting production and possessing 
stable buyers. Such ties with buyers also depend on the type of farm and its scale of production: in the group with an area of 1-5 hectares, only around $11 \%$ have permanent buyers, while $49 \%$ of farms over 50 hectares have such customers. The process of vertical integration with agri-business has thus occurred primarily in larger farms. 'Taking into consideration that the nature of market contacts is a factor that differentiates professional agricultural producers from general farm users ...' (the farm constituting the main place of work for the head of the farm and agricultural activity being the income base), it can be estimated that in the 'group of farm users studied in 2011, around 26\% fulfilled the above criteria' (Sikorska, ibid.: 61). If these estimates are applied to the group of all individual farms, in 2012 in Poland there were around 400,000 'professional' farms.

The differences in the traits of farms and their manners of functioning are quite varied, as is illustrated in table 3: each of the groups of farms with different areas appears to operate according to its own rationale, fulfilling a different function in the economy and in family arrangements. This concerns, above all, the group of the smallest farms, with an area of 1-5 hectares, and the larger farms, with an area greater than 15 hectares.

Small farms, in the category of 1-5 hectares, are farms producing primarily for self-sufficiency. Here only around 3\% of farms are 'professional farms' in Sikorska's sense. But they are also the farms that employ half (50\%) of all persons working in agriculture, even though during the most recent period (since 2005) there has been a decline in employment. These are farms which have a low scale of production, but which are not reducing their areas, because attachment to the land, as it once existed, has now been strengthened/ replaced by the possibility of acquiring direct payments (treated as due payment for possession of the land). This is passive farming, without concern for the size or intensity of production, and without introducing innovations or planning for further development. Only for a small number of families does the farm constitute the main source of income. Non-agricultural incomes ensure the farm-holders of income autonomy, which leads to a singular kind of rationale for farming, in an extensive or even sham manner. It is also very rare to encounter initiatives for transforming the farm into a rural business by combining farming with another non-agricultural activity. This manner of functioning makes it possible to call these farms 'semi-peasant farms'. This type of farm in Poland predominates by number and percentage, as over half of all farms belong in this category. 
Table 3. Basic characteristics of private (individual) farms (PF) of over 1 ha engaged in agricultural production in 2010. Data in percentages

\begin{tabular}{|c|c|c|c|c|c|}
\hline \multirow{2}{*}{ Characteristic } & \multicolumn{5}{|c|}{ Area groups of farms in hectares } \\
\hline & Total & $1-5$ & $5-15$ & $15-50$ & $>50$ \\
\hline $\begin{array}{l}\text { No. of farms in thousands } \\
\text { Structure in } \%\end{array}$ & $\begin{array}{c}1,480.2 \\
100.0\end{array}$ & $\begin{array}{c}790.0 \\
53.6\end{array}$ & $\begin{array}{c}497.0 \\
32.4\end{array}$ & $\begin{array}{c}168.9 \\
10.8\end{array}$ & $\begin{array}{c}24.3 \\
1.4\end{array}$ \\
\hline $\begin{array}{c}\text { Revenues are chiefly agricultural } \\
(>50 \% \text { from agriculture }) \\
(\% \text { of } \mathrm{PF})\end{array}$ & 34.1 & 13.6 & 48.5 & 80.3 & 83.5 \\
\hline Functioning farms in $\%$ of group & 89.6 & 82.7 & 99.2 & 98.4 & 99.9 \\
\hline Farms raising livestock in \% & 61.4 & 49.8 & 78.9 & 78.6 & 57.9 \\
\hline AWU/farm & 1.24 & 0.91 & 1.48 & 1.93 & 2.30 \\
\hline Working exclusively in farm/PF & 1.6 & 1.34 & 1.82 & 2.28 & 1.89 \\
\hline $\begin{array}{c}\text { Sale of }>75 \% \text { of farm } \\
\text { production }\end{array}$ & 52.3 & 44.6 & 56.8 & 70.7 & 80.9 \\
\hline $\begin{array}{l}\text { Self-supply }>75 \% \text { of farm } \\
\text { production }\end{array}$ & 29.3 & 41.4 & 19.9 & 4.2 & 0.0 \\
\hline $\begin{array}{l}\text { Direct sales: not practised at all, } \\
\text { in } \% \text { of PF }\end{array}$ & 41.5 & 37.4 & 43.4 & 51.4 & 60.9 \\
\hline $\begin{array}{c}\text { Direct sales }>75 \% \text { of production, } \\
\text { in } \% \text { of PF }\end{array}$ & 10.2 & 11.4 & 10.5 & 7.6 & 10.2 \\
\hline $\begin{array}{l}\text { Farms receiving RDP funds, } \\
\text { in } \%\end{array}$ & 8.81 & 1.91 & 9.48 & 29.03 & 58.54 \\
\hline $\begin{array}{c}\text { Absorption of family labour } \\
\text { force } \\
\text { thousands of people } \\
\text { thousands of AWU }\end{array}$ & $\begin{array}{l}3,547.0 \\
1,745.3\end{array}$ & $\begin{array}{l}50.0 \\
39.5\end{array}$ & $\begin{array}{l}40.8 \\
47.9\end{array}$ & $\begin{array}{c}7.4 \\
10.2\end{array}$ & $\begin{array}{l}1.8 \\
2.4\end{array}$ \\
\hline
\end{tabular}

Source: own study based on GUS (2012).

In contrast to these are the largest farms, with over 15 hectares. According to the data, only one in eight individual farms in Poland has this much land. Almost all fulfil the criteria of professional farms. These are farms set on mass production for the market; their owners maintain themselves chiefly from agriculture, modernise their farms, and make use of common agricultural policy support. It is a varied group, in which one can distinguish modernising family farms, family agri-businesses, and agri-businesses with non-family traits and non-family rationales of operation. 
Thirdly, these groups of farms appear to follow different family strategies, as indicated by the characteristics of their directors and by types of management. In the group of quasi-peasant farms, a decidedly larger-thanaverage role is played by women and by older - or definitely elderly - persons. Professionalism, as measured by the head of the farm's vocational preparation in agriculture, is low here; there is very little engagement with the farm, as is shown by the amount of time spent working on it. When the head of the farm has a good general education, including a higher education, this is indicative of a career in a non-agricultural occupation. At the same time, in this group in the last 10 years, as many as $1 / 3$ of farms changed their head. I believe that this signals the existence of a family strategy connected with the farm, which assures family security and social privilege. To the two previous aspects of autonomy associated with a family farm - freedom from the market and the lack of necessity of maintaining/feeding the family - the social security of family members and, thanks to the prosthesis of the farmer's social status, psychological well-being are combined.

Table 4. The characteristics of managers of different types of family farms

\begin{tabular}{|c|c|c|c|c|c|}
\hline \multirow[b]{2}{*}{ Features/rates } & \multirow{2}{*}{$\begin{array}{c}\text { Farms } \\
>1 \text { ha in total } \\
\text { Average of the } \\
\text { feature }= \\
100 \%\end{array}$} & \multicolumn{4}{|c|}{ Area groups of farms } \\
\hline & & $1-5$ ha & $\begin{array}{c}5-15 \\
\text { ha }\end{array}$ & $\begin{array}{c}15-50 \\
\text { ha }\end{array}$ & $\begin{array}{l}50 \text { or } \\
\text { more ha }\end{array}$ \\
\hline $\begin{array}{l}\text { Percentage of managers aged } \\
>65 \text { years in } \%\end{array}$ & 10.9 & 12.0 & 4.1 & 1.6 & 2.0 \\
\hline $\begin{array}{c}\text { Percentage of women among } \\
\text { managers }\end{array}$ & 30.8 & 39.5 & 23.0 & 8.7 & 11.0 \\
\hline Rate of generational renewal & 83 & 120 & 86 & 72 & 80 \\
\hline $\begin{array}{c}\text { Professionalisation: \% of managers } \\
\text { with agricultural } \\
\text { preparation/background }\end{array}$ & 46.1 & 35.0 & 53.9 & 70.9 & 74.1 \\
\hline $\begin{array}{l}\text { The ratio of those working below } \\
530 \text { hours per year to those working } \\
\text { more than } 1,590 \text { hours per year }\end{array}$ & 163 & 64 & 417 & 1,600 & 1,200 \\
\hline Managers with higher education in \% & 10.0 & 10.8 & 8.4 & 8.8 & 21.3 \\
\hline
\end{tabular}

Source: own study based on GUS [2012a].

* Generational renewal rate is the proportion of "new" farmers ( $<10$ years) to the "old" (>21 years). 
On the other hand, in the group of professionalising family farms and family agri-businesses, there is an accumulation of contrary traits: here the farm is an affair for a mature man, well prepared vocationally, focused on agriculture, and having considerable experience in running a farm. The family tie to such a farm is strong, as the farm constitutes the family's main source of livelihood. The family, through farming, meets its material needs (as defined by consumer society) and is directed by the principle of their better fulfilment, which presupposes (doubtlessly) a desire to maximise income. This means that the farm becomes dependent on the market and its variable requirements, ${ }^{22}$ which, in turn, determines the internal mechanisms of its transformation.

\section{Dual agriculture: a transitional state or one of long duration?}

For 25 years, family farms have been changing; these changes are occurring much faster than in the entire 40-year period preceding 1989. During the whole period, the number of farms decreased by around $14 \%$, which on a yearly basis amounts to .3 of a percentage point. These changes have led to the large differentiation of farms, which follow two divergent trajectories: the majority of farms are sited on the declining trajectory, with the dynamic minority on the rising one. The rising trajectory is shaped by a group of modern, market-oriented farms in a conventional, traditional manner. The impact of the 'balanced development' paradigm is not (yet?) visible. The group of farms located on the declining trajectory would appear to be much more interesting, particularly the group of quasi-peasant farms. The manner of this group's adaptation to new conditions contains - in my opinion innovative elements. The owners of this group of (agricultural?) farms have social security, act in the name of varied family interests, and produce when and what they please. Quasi-peasant farms and quasi-peasants are,

22 '...on account of the continuing dispersal of producers, the market for agricultural products is becoming increasingly a buyer's market. In general, purchasers have large material resources and dictate sale conditions to the farmers, and in the generally unstable economic situation are uninterested in entering into long-term contracts' (Ibid., p. 5). In turn, the producers, particularly the smallest, are not very inclined towards self-organisation, which would help them in achieving a position of market parity. Less than $2 \%$ of farmers have such potential. 
in my opinion, an original product of arrested collectivisation/hindered modernisation, the post-communist transformation, and the controlled dual modernisation.

It is worth considering to what degree this is a permanent group, and to what degree it is transitional, particularly as this is a very large group, and a product not only of the past but also of present conditions. In analysing this group through the prism of the third premise of the analysis - plans for the future - what should be taken into consideration are not only the plans of the owners of these farms but also the intentions of politicians who decide about agricultural policy. The users of these farms are, as mentioned, a group with a specific socio-demographic character. The tempo of change in the heads of farms indicates, on the one hand, a strategy of ensuring the future and, on the other hand, a change caused - more frequently than in the other groups of farms - by the death of a spouse (cf. the indicators of age and feminisation). In spite of the higher indicator of old age in this group, according to data of the General Agricultural Census, the intent to transfer the farm to a successor is declared by only $8 \%$ of the heads of such farms compared with $11 \%$ in the group of 15 hectares or more. At a similar level in both groups (over $80 \%$ ), the successor is to be a member of the family; in the quasipeasant group, the dose of uncertainty is larger, though, because as many as $17 \%$ (compared to $11 \%$ ) of farms do not have an established successor. This forms a fairly cohesive long-duration trajectory: the completed transition at the head of the farm and a rarer intent to transfer the farm to a successor, who is more difficult to find in this case than in the group of larger farms. This doubtlessly produces the fairly large number of sales of these farms, as well as the rationalisation of their structures: a slight increase in average area, and a drop in employment. The basic factors for their survival are to be found, therefore, in the 'present situation', which is defined by the condition of the whole economy (above all, its ability to absorb hidden unemployment) and by political decisions to maintain the above-mentioned numerous social and fiscal privileges. Nevertheless, as the numerous quasi-peasants are a tasty electoral morsel for many political forces in Poland, the quasi-peasant farms are unlikely to disappear soon from the landscape. 


\section{References}

Baer-Nawrocka, A., Poczta W., 2014. Przemiany $w$ rolnictwie ['Changes in Agriculture'], [in]: Polska wieś 2014. Raport o stanie wsi [Rural Poland 2014: A Report on the State of Rural Areas], I. Nurzyńska, W. Poczta (ed.). Scholar, Warsaw, pp. 85-124.

Chałasiński, J., 1938. Młode pokolenie chłopów [The Young Generation of Peasants]. Państwowy Instytut Kultury Wsi [National Institute for Rural Culture], Warsaw.

Cywiński, B., 1981. ... potęga jest - $i$ basta [...There's a Power, and That's That]. Krąg, Warsaw.

Errington A., Gasson R., 1993. The Family Farm Business. CAB International, Wallingford.

Dzun, W., 2013. Drobne gospodarstwa $w$ rolnictwie polskim. Próba definicji i charakterystyki ['Small Farms in Polish Agriculture: An Attempt at Definition and Characterization']. Wieś i Rolnictwo [Rural Areas and Agriculture] no. 2, pp. 9-27.

Frenkel, I., 2013. Zatrudnienie i struktura zatrudnienia $w$ gospodarstwach rolnych $w$ latach 2005-2010 [Employment and the Structure of Employment on Farms in the Years 2005-2010], Institute for Rural and Agricultural Development of the Polish Academy of Sciences, Warsaw.

Foryś, G., 2008. „Dynamika sporu. Protesty rolników w III Rzeczpospolitej” ['Growth of a Dispute: Farmers' Protests in the 3rd Republic'], Scholar, Warsaw.

Frenkel, I., 2014. Ludność wiejska ['The Rural Population'],[in]: Polska wieś 2014. Raport o stanie wsi [Rural Poland 2014: A Report on the State of Rural Areas], I. Nurzyńska, W. Poczta (ed.). Scholar, Warsaw, pp. 27-84.

Gorlach, K., 2001. Świat na progu domu [The World at One's Doorstep]. Jagiellonian University Press, Kraków.

Gorlach, K., Seręga Z., 1993. 'From Repressive Tolerance to Oppressive Freedom: Polish Family Farms in Transition', [in:] J.C. Huther, B. Synak, Post-Communist Poland: From Totalitarianisn to Democracy? Nova Science Publisher, Commack, N.Y.

Gorlach, K., 1989. On Repressive Tolerance: State and Peasant Farm in Poland. Sociologia Ruralis, 29(1), Pp. 23-33. Available at: Http://Dx.Doi. Org/10.1111/J.1467-9523.1989.Tb00353.X.

Halamska, M., 2014. Współczesne rolnictwo rodzinne: polimorficzna rzeczywistość $i$ mity ['Contemporary Family Farming: Myths and the Polymorphic Reality']. Wieś i Rolnictwo, no. 2, pp. 25-46.

Halamska, M., 2013. Wiejska Polska na początku XXI wieku. Rozważania o gospodarce $i$ społeczeństwie [Rural Poland at the Beginning of the 21st Century: Reflections on the Economy and Society]. Scholar, Warsaw.

Halamska, M., 2004. 'A Different End of the Peasants?', Polish Sociological Review, no. 3 (147), pp. 245-268. 
Halamska, M., Lamarche, H., Maurel, M.-C., 2003. Rolnictwo rodzinne w transformacji postkomunistycznej. Anatomia zmiany [Family Farming in the Post-Communist Transformation: An Anatomy of Change]. Institute for Rural and Agricultural Development of the Polish Academy of Sciences, Warsaw.

Halamska, M., 1999. 'Peasants, Ownership and Socialism in Poland: Historical and Some Other Reflections' [in:] Rural Societies under Communism and Beyond, P. Starosta, I.Kovach, K.Gorlach (eds.). Łódź University Press, Łódź, pp. 44-53.

Halamska, M., 1989. Gospodarstwo rodzinne a struktury organizacyjne gminy ['Family Farms and the Organizational Structure of Districts'], [in:] Środowisko gminne [The District Environment], D. Gałaj (ed.). Ludowa Spółdzielnia Wydawnicza [People's Cooperative Publishing], Warsaw 1989, pp. 273-299.

Kochanowicz, J., 1988. Losy gospodarki chłopskiej w niekapitalistycznej próbie modernizacji ['The Fates of Peasant Farms in the Non-Capitalist Attempt at Modernization' [in;] Gospodarka chłopska w systemie gospodarki socjalistycznej [Peasant Economy in the Communist Economic System], J.Wilkin (ed.). Department of Economics of the University of Warsaw, Warsaw, pp. 62-91.

Kuczyński, W., 1981. Po wielkim skoku [After the Great Leap]. PWE, Warsaw.

Marini, M.B. \& Mooney, P.H., Rural Economies. The Handbook of Rural Studies, pp. 91-103. Available at: http://dx.doi.org/10.4135/9781848608016.n6.

Maurel, M-C., 1989. Les paysans contre l'Etat. Harmattan, Paris.

Mendras, H., 1997. L'Europe des Européens. Gallimard, Paris.

Maurel, M.-C., Lamarche, H., Halamska, M., 2003: Le repli paysan. Harmattan, Paris. Ploeg van der, J.D., 2008. The New Peasantries: Struggle for Autonomy and Sustainability in an Era of Empire and Globalisation. Sterling V, London.

Rowiński, J. 2008. Program Rozwoju Obszarów Wiejskich na lata 2007-2013. Analiza zatwierdzonej wersji programu i pierwszych lat realizacji [Rural Development Programme for the Years 2007-2013: Analysis of the Approved Version of the Programme and the First Years of Implementation]. Institute of Agricultural and Food Economics of the Polish Research Institute, Warsaw.

Servolin, C., 1989. Lagriculture moderne. Ed. Seuil, Paris.

Sieliwończyk ,P., 1983. Władyslaw Grabski: Wieś i rolnictwo na tle solidarystycznej koncepcji narodu" [Władyslaw Grabski: Rural Areas and Agriculture in the Context of a Solidary Concept of the Nation'] [in:] Szkice $w$ historii $i$ socjologii polskiej [Essays on Polish History and Sociology], K.Z. Sowa (ed.). PAX, Warsaw.

Sikorska, A., 2013. Procesy przekształceń strukturalnych $w$ wiejskiej społeczności $i$ chłopskim rolnictwie [The Processes of Structural Transformations in Rural Society and Peasant Farming]. Institute of Agricultural and Food Economics of the Polish Research Institute, Warsaw.

Sikorska, A., 2014. Dylematy $w$ definiowaniu rodzinnych gospodarstw rolnych ['Dilemmas in Defining Family Farms']. Zagadnienia Ekonomiki Rolnej [Issues of Agricultural Economics] no.4, pp. 31-49. 
Sivignon, M., 1992-1993. La diffusion des modèles agricoles: essai d'interprétation des agricultures de l'est et du sud de l'Europe. Revue Géographique des Pyrenées et du Sud-Ouest, vol. 63, fasc. 2, pp. 133-153.

Sowa, J., 2014. Fantomowe ciało króla [The Phantom Body of the King]. Universitas, Kraków.

Stronge, M., 2008. Family Farming: A New Economic Vision. University of Nebraska Press, Lincoln ( $1^{\text {st }}$ edition 1988).

Szafraniec, K., 2002. Polskie residuum systemowe, czyli pytanie o role wsi i chłopów w procesie przemian systemowych ['Poland's Systemic Residuum, or the Question of the Role of the Countryside and of the Peasants'],[in:] Wies i rolnictwo. Perspektywy rozwoju [Rural Areas and Agriculture: Development Perspectives]. Institute of Agricultural and Food Economics, Institute for Rural and Agricultural Development of the Polish Academy of Sciences, Warsaw School of Economics, Warsaw.

Szczepański, J., 1973. Zmiany społeczeństwa polskiego pod wplywem uprzemystowienia [Changes in Polish Society Under the Impact of Industrialization]. CRZZ, Warsaw.

Tepicht J., 1973: Marxisme et agriculture. Le paysan polonais. Armand Colin, Paris.

Tomczak, F., 1988. Gospodarka rodzinne w rolnictwie. Teraźniejszość i przyszłość [Family Farming in Agriculture: Past and Present]. National Agricultural and Forestry Publishing, Warsaw.

Wilkin, J., 1988. Chłopski skladnik losów gospodarki socjalistycznej (ze szczególnym uwzglednieniem polskich doświadczeń) ['The Peasant Contribution to the Fate of Communist Economics (with Particular Consideration of the Polish Experience)'], [in;] Gospodarka chłopska w systemie gospodarki socjalistycznej [Peasant Economics in the Communist System of Economics], J.Wilkin (ed.). Department of Economics of the University of Warsaw, Warsaw, pp. 7-35.

Wilkin, J., 2013. Aksjologia i prakseologia polityki wobec drobnych gospodarstw w Polsce i Unii Europejskiej ['The Axiology and Praxeology of Policies on Small Farms in Poland and the European Union']. Wieś i Rolnictwo [Rural Areas and Agriculture], no. 2., pp. 43-54. 